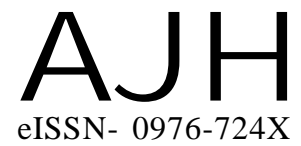

Received : 04.03.2016

Revised : 24.04.2016

Accepted : 04.05.2016

Author for correspondence

SWATI SHARMA

ASPEE Agribusiness Management Institute, Navsari Agricultural

University, NAVSARI (GUJARAT) INDIA

Email : swatisharma_abm@yahoo.

co.in
THEASIAN JOURNALOF HORTICULTURE

Volume 11 | Issue $1 \mid$ June, 2016 | 124-128

Visit us -www.researchjournal.co.in

RESEARCH PAPER

DOI : 10.15740/HAS/TAJH/11.1/124-128

\title{
Economic analysis of post harvest losses in onion in Jaipur district of Rajasthan
}

\section{SWATI SHARMA}

ABSTRACT : A study was undertaken to examine the nature and extent of post-harvest losses in onion supply chain in the Jaipur district which is major onion district of Rajasthan. A total sample size of 75 onion growers, 20 wholesalers and 25 retailers was taken from Jaipur district. Maximum aggregate post-harvest losses $(23.96 \mathrm{~kg} / \mathrm{q})$ have been found at producer level due to faulty storage, lack of adequate transportation, drying, improper handling of the produce at the time of marketing, rotted bulbs, doubles, bolters, poor packing facilities, injury at the time of harvesting and de-topping. Total losses in the supply chain were estimated to be $28.99 \mathrm{~kg} / \mathrm{q}$ $(82.65 \%)$ losses were observed at farm level and rest were contributed at wholesale and retail level. The farm level post harvest losses excluding the losses at farm level storage for Jaipur district was estimated to be 5185.20q for the year 2009-10.

KEY WORDS : Post-harvest losses, Onion, Supply chain, Storage

HOW TO CITE THIS ARTICLE : Sharma, Swati (2016). Economic analysis of post harvest losses in onion in Jaipur district of Rajasthan. Asian J. Hort., 11(1) : 124-128, DOI : 10.15740/HAS/TAJH/11.1/ 124-128. 